О.О. Борисов, аспірант, ORCID 0000-0002-1053-2989

O.С. Кофанов, канд. тех. наук, асистент, ORCID 0000-0003-2181-9288

Національний технічний університет України «Київський політехнічний інститут імені Ігоря Сікорського»

\title{
ЕКОЛОГІЧНЕ НАВАНТАЖЕННЯ 3 БОКУ АВТОТРАНСПОРТНИХ ПОТОКІВ НА ПРИДОРОЖНІ ТЕРИТОРІї РЕКРЕАЦІЙНОГО ПРИЗНАЧЕННЯ
}

У роботі досліджено вплив автотранспортних потоків на міські придорожні території рекреаційного призначення (на прикладі зон відпочинку м. Києва). Актуальність дослідження зумовлена тим, щуо значна частина міського населення Украӥни мешкає в умовах підвищених, високих або навіть дуже високих рівнів забруднення навколишнього середовища. Проблема посилюється тим, щзо останніми роками в країні все частіше експлуатуються уживані автотранспортні засоби з двигунами екологічних класів Євро 1... Свро 3. Емпірично встановлено, щзо на процеси розсіювання і концентрування забруднювачів на певних територіях впливають напрям і швидкість вітру, метеорологічні умови, фізико-хімічні властивості речовини-забруднювачів, процеси їх трансформації у довкіллі, а також умови седиментації та/або вторинного механічного перенесення. Для прогнозування екологічного стану досліджуваних територій у середовищі MathCad на основі розв'язку рівняння турбулентної дифузії побудовано просторові математичні моделі полів концентрачій шкідливих домішок, зокрема оксидів Нітрогену, Карбону та дрібнодисперсного пилу РМ за небезпечних напрямків та швидкості вітру. За результатами моделювання встановлено, щзо досліджувані території, щзо є зонами активного відпочинку людей, можуть бути потенційно небезпечними для здоров'я через шкідливий вплив викидів автотранспортних потоків розташованих поряд автомагістралей. За допомогою обчислювального експерименту спрогнозовано розвиток екологічної ситуації на циих територіях за певної транспортної ситуації та метеорологічних умов.

Ключові слова: автотранспортний потік, екологічна безпека, шкідливі речовини, викиди автотранспортних засобів, рекреаційні території, зони відпочинку, забруднення довкілля.

Вступ. Бурхливі урбанізаційні процеси та явища, що їх супроводжують (зростання частки міського населення, розростання території міст, розвиток транспортних зв'язків і потоків тощо), є найбільш характерними для сучасного суспільства. Як наслідок, у великих містах і передмістях спостерігається значне порушення стану навколишнього природного середовища (НПС) через створення нової екосистеми урбоекосистеми, яка розвивається під впливом не стільки природних, скільки антропогенних чинників. У містах знижується інтенсивність сонячної радіації, формуються так звані "острови тепла", створюються умови для виникнення туманів, смогів тощо, підвищується кількість опадів (у тому числі й кислотних), збільшуються площі техногенно забруднених територій. Все це, а також багато інших негативних чинників міського середовища впливають на здоров'я і психічний стан населення. Отже, оцінювання та підтримання належного екологічного стану міських територій, особливо територій оздоровчого призначення, має велике значення.

Постановка проблеми. Спеціалісти виокремлюють три основні різновиди екологічної небезпеки, що зумовлені активною антропогенною діяльністю [1], а саме:

- соціально-екологічна небезпека, обумовлена погіршенням екологічного стану середовища проживання людини та загрозою її здоров’ю;

- біосферно-екологічна - спричинена загрозою порушення природної рівноваги на Землі;

- ресурсно-екологічна небезпека, зумовлена скороченням природно-ресурсного потенціалу, деградацією природних ресурсів, їх вичерпністю тощо.

3 точки зору забезпечення сталого збалансованого розвитку урбанізованих територій та підвищення екологічної безпеки міського населення існує багато шляхів поліпшення екологічності автотранспортних засобів (АТЗ), що рухаються дорогами країни. Проте більшість з відомих способів надають можливість скоротити обсяги викидів шкідливих речовин (ШР) з відпрацьованими газами (ВГ) АТЗ, зменшити їх токсичність тощо, проте не вирішують головної проблеми - проблеми запобігання забрудненню НПС. За даними Міністерства інфраструктури України, на даний час автотранспортна система України налічує більше 9,2 млн. транспортних засобів, у тому числі 6,9 млн. легкових автомобілів, 250 тис. автобусів, 1,3 млн. вантажних автомобілів і понад 840 тис. одиниць мототранспорту. А враховуючи постійне

(C) О.О. Борисов, О.С. Кофанов, 2019 
зростання кількості АТЗ в Україні та світі загалом, вирішення проблеми моніторингу й захисту довкілля від впливу автотранспортних потоків (АТП) є актуальним і своєчасним завданням, яке потребує грунтовного дослідження.

Метою роботи є оцінка екологічного тиску з боку автотранспортних потоків на придорожні міські території рекреаційного призначення (на прикладі зон відпочинку м. Києва).

Аналіз останніх досліджень. Вивчення стану здоров'я міського населення та його залежності від екологічних чинників надає важливу інформацію для вирішення завдань охорони НПС. Особливо важливою у цьому контексті є кількісна оцінка потенційного екологічного ризику здоров'ю населення, зумовленого вПливом АТП на міських територіях оздоровчого призначення. Ю. П. Гічевим [2] було розроблено класифікацію екологічно значущих захворювань людей та виокремлено три основні групи патологічних процесів, які залежать від стану навколишнього середовища, а саме:

- індикаторна екологічна патологія, яка відображає високий ступінь залежності стану здоров’я населення від забруднення НПС. Це, наприклад, професійні хвороби, онкологічні захворювання, перинатальна смертність, вроджена патологія, генетичні вади, різноманітні алергічні реакції тощо;

- екологічно залежна патологія, що відображає середній ступінь залежності стану здоров'я населення від забруднення НПС. Сюди відносять такі індикатори, як смертність немовлят, смертність дітей раннього віку, загальну дитячу смертність, вторинні імунодефіцити, хронічний бронхіт і пневмонію у дітей, хронічні паренхіматозні враження печінки і жовчовивідних шляхів, загострення основних захворювань дихальної та серцево-судинної систем при погіршенні метеорологічних умов у містах;

- екологічно обумовлена патологія відображає помірну залежність стану здоров'я людей від стану НПС. Це, зокрема, статистичні дані щодо спонтанних викиднів, патологій вагітності, захворювань на хронічний бронхіт і пневмонію у дорослих, анемію у дітей, основні захворювання серцево-судинної системи тощо.

Таким чином, оцінка стану НПС та прогнозування наслідків техногенного навантаження з боку АТП на здоров'я людей, а також розробка превентивних заходів щодо забруднення міських територій рекреаційного призначення є актуальним завданням, яке потребує вивчення умов життя й відпочинку мешканців міст на придорожніх територіях.

Стан НПС оцінюють за вмістом в його основних компонентах (атмосфері, гідросфері, педосфері, біосфері в цілому) певних забруднювачів, а також за інтенсивністю негативних фізичних чинників - шуму, вібрації, радіоактивного випромінювання, електромагнітних полів тощо. Основними джерелами таких забруднень $є$ не тільки стаціонарні, а й пересувні джерела - АТЗ. Географічне положення міста, його рельєф, тип та щільність забудови, наявність/відсутність водних об'єктів, площа зелених насаджень та їх видовий склад тощо також великою мірою впливають і на кліматичні умови, і на циркуляцію повітряних мас та, як наслідок, - на умови розсіювання чи локального концентрування забруднювачів на певній території.

Для визначення рівня забруднення атмосферного повітря (РЗ Ап) населених пунктів використовують

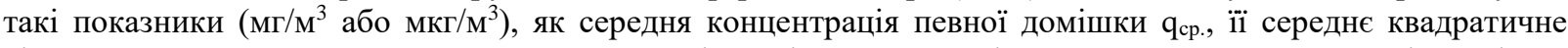
відхилення б та максимальна разова концентрація домішки q з відповідними значеннями ії гранично допустимих концентрацій (ГДК) надає інформацію про РЗ Ап певної території. При цьому середні концентрації порівнюють з середньодобовими значеннями ГДК с.д. домішки, а максимальні з разових - з ГДК м.р. цієї домішки [3].

Якість повітря певної території (району, міста в цілому) оцінюють за інтегральним (комплексним) індексом забруднення атмосфери (IЗА або КІЗА), який розраховують, як правило, за середньорічними (середньомісячними) концентраціями домішки за формулою (1) і який враховує ступінь шкідливого впливу певного комплексу забруднювачів, характерних саме для цієї території, на живі організми:

$$
\mathrm{I} 3 \mathrm{~A}=\Sigma\left[\mathrm{C}\left(\mathrm{X}_{\mathrm{i}}\right) / \text { ГДКс.д. }\left(\mathrm{X}_{\mathrm{i}}\right)\right] \mathrm{a}_{\mathrm{i}}, \quad \text { ум. од., }
$$

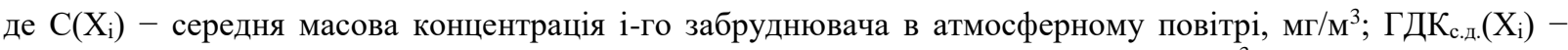

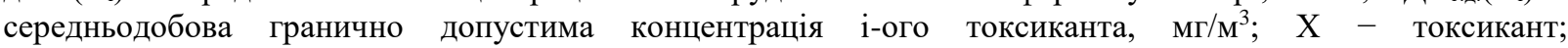
$\mathrm{a}_{\mathrm{i}}$ - коефіцієнт, що враховує ступінь шкідливості токсиканту порівняно зі шкідливістю речовини 3 -го класу небезпеки (зокрема $\mathrm{SO}_{2}$ ).

Для речовин 1-го класу небезпеки коефіцієнт аі встановлений 1,7; 2-го класу - 1,3; 3-го класу - 1,0, і для речовин 4-го класу небезпеки він дорівнює 0,9 [3]. Таким чином, показник IЗА, розрахований за 5-ма характерними для даної території забруднювачами, може слугувати чутливим індикатором для встановлення зв'язку між РЗ Ап $\mathrm{i}$ рівнем захворюваності населення на певні хвороби, що зумовлені станом НПС.

Викладення основного матеріалу. У дослідженні, відповідно до статистичних даних Центральної геофізичної обсерваторії імені Бориса Срезневського (ЦГО, м. Київ), для розрахунку ІЗА обрано домішки $\mathrm{CO}, \mathrm{NO}_{2}, \mathrm{PM}$ (дрібнодисперсні частинки сажі, пилу тощо), $\mathrm{SO}_{2}$ та формальдегіду (ФА). При значенні I3А < 5 рівень забруднення атмосферного повітря вважали низьким, $5 \div 7-$ підвищеним, $7 \div 14-$ високим і вище $14-$ 


\section{ISSN 1813-5420 (Print). Енергетика: економіка, технологіï, екологія. 2018. № 4}

дуже високим [4]; для характеристики РЗ Ап окремими полютантами застосовували парціальні I3A( $\left.\mathrm{X}_{\mathrm{i}}\right)$. На рис. 1 показано значення IЗА за 2011-2018 рр. Як можна побачити, РЗ Ап у м. Києві за останні роки $є$ стабільно високим.

Ще одним показником якості повітря є стандартний індекс забруднення (CI) - найбільша встановлена разова концентрація певного забруднювача, поділена на величину його ГДК [5]. Як правило, цей показник оцінюють за кількістю постів спостережень, де зафіксовано перевищення ГДК певної домішки. Тоді при

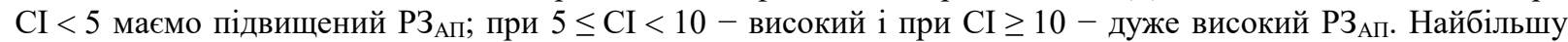
повторюваність перевищення ГДКм.р. (\%) за даними спостережень на одному посту спостережень за однією домішкою або на всіх постах території за всіма токсикантами за певний період часу називають найбільшою повторюваністю перевищень ГДК (НПП). Якщо НПП <20\% - Р3 АП вважають підвищеним; при $20 \% \leq$ НПП < 50 \% - високим і при НПП $\geq 50$ \% - дуже високим [6].

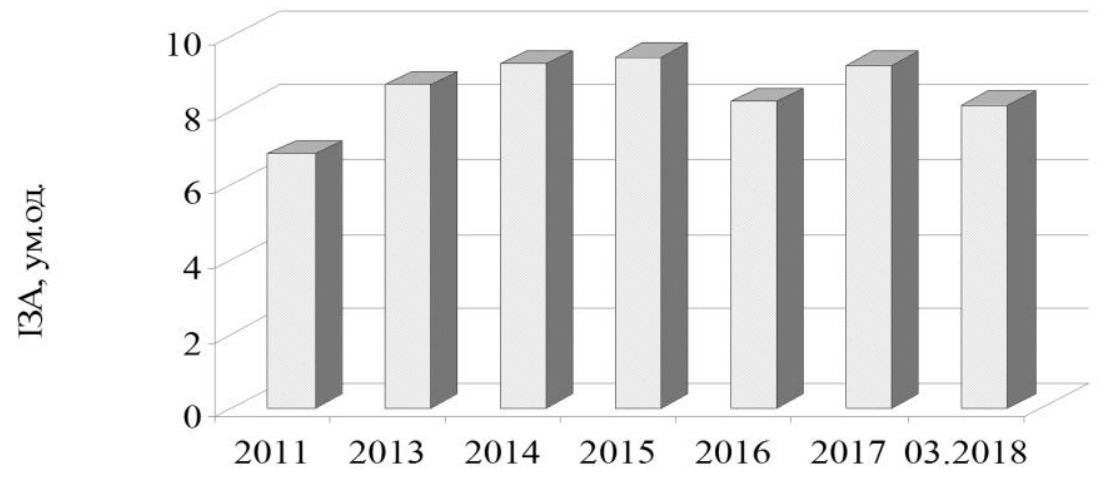

Роки

Рисунок 1 - IЗА по м. Києву за багаторічними спостереженнями [узагальнено та побудовано авторами за даними ЦГО, м. Київ].

У природних водах міграція хімічних елементів (XЕ) відбувається також досить інтенсивно. При цьому, як правило, спостерігається зміна якісного й кількісного складів природних вод (іх метаморфізація). Зокрема, у воді та донних відкладеннях, органах рослин і тварин накопичуються сполуки Хлору, Сульфуру, Нітрогену, Карбону, Натрію, Кальцію, Магнію, важких металів (BM) тощо та чинять негативний вплив на здоров'я тварин і людей. Особливо небезпечним є забруднення територій оздоровчого призначення, де дорослі з дітьми проводять тривалий час, навіть не здогадуючись про потенційну небезпеку. Такі території, як правило, підлягають комплексному забрудненню - погіршується не тільки стан атмосферного повітря $\mathrm{i}$ водойм, а й грунтового покриву, рослинності, тваринного світу тощо.

Шкідливий вплив інгредієнтів ВГ АТЗ дуже різноманітний. Бенз(а)пірен, альдегіди, Сульфур(IV) оксид, оксиди Нітрогену й Карбону здатні спричинювати ускладненість дихання, астматичні ефекти, провокувати бронхіти й пневмонії (особливо у дітей), зростання кількості випадків захворюваності на рак тощо. З ВГ двигунів внутрішнього згоряння до атмосфери, грунтів і водойм потрапляють дрібнодисперсні частинки сажі, масел, продуктів зносу дорожнього покриття, двигунів та іншого обладнання.

Основна частина викидів оксидів Нітрогену $\mathrm{NO}_{x}$ припадає на Нітроген(II) оксид NO i Нітроген(IV) оксид $\mathrm{NO}_{2}$. В атмосфері $\mathrm{NO}$ під впливом окисників швидко (від 0,5 до 100 год. залежно від його концентрації у повітрі) перетворюється на $\mathrm{NO}_{2}$. Вміст інших оксидів Нітрогену $\left(\mathrm{N}_{2} \mathrm{O}, \mathrm{N}_{2} \mathrm{O}_{3}, \mathrm{~N}_{2} \mathrm{O}_{4}, \mathrm{~N}_{2} \mathrm{O}_{5}\right)$ у ВГ невеликий. Оксиди $\mathrm{NO}_{\mathrm{x}}$ беруть участь у фотохімічних перетвореннях під дією сонячного опромінення та спричинюють формування умов для виникнення фотохімічного смогу. Вони також шкодять бронхам, впливають на міокард і слизові оболонки носа, очей, шлунка, на стан центральної нервової системи людини, на фотосинтетичний апарат рослин тощо. А наявність у ВГ незгорілих вуглеводнів значно посилює їх токсичність через синергетичну дію. При цьому одним із продуктів фотохімічних перетворень за участю $\mathrm{NO}_{x}$ та вуглеводнів є приземний озон, який, на відміну від тропосферного, шкідливо діє на НПС і здоров’я людей.

При взаємодії $\mathrm{NO}_{x} 3$ водою чи водяною парою в повітрі утворюються дрібнодисперсні аерозолі нітритної $\mathrm{HNO}_{2}$ i нітратної $\mathrm{HNO}_{3}$ кислот. Аналогічні процеси відбуваються i при контакті Нітроген(IV) оксиду з вологими поверхнями дихальних шляхів людини і вищих тварин. Потрапляючи у кров, оксиди Нітрогену порушують транспортну функцію гемоглобіну, а під впливом ферментів мікрофлори шлунка й кишківника перетворюються на нітрити і нітрати. 
Наслідки шкідливого впливу Карбон(II) оксиду СО на організм людини залежать від його концентрації у повітрі. Зокрема, при концентрації до $0,05 \%$ через годину у людей з'являються ознаки отруєння, а при концентрації вище $1 \%$ людина втрачає свідомість [7]. ВМ пригнічують ферментну активність, процеси дихання, фосфорилірування й активного транспорту, спричиняючи функціональні та морфологічні зміни у мітохондріях, скорочення терміну "життя" еритроцитів, сповільнення синтезу гемоглобіну і порушення метаболізму. Крім того, вони мають кумулятивну дію через здатність до утворення досить міцних металоорганічних комплексів.

Альдегіди $\mathrm{RC}(\mathrm{O}) \mathrm{H}$ (зокрема, формальдегід $\mathrm{HC}(\mathrm{O}) \mathrm{H}$ і акролеїн $\left.\mathrm{C}_{2} \mathrm{H}_{3} \mathrm{C}(\mathrm{O}) \mathrm{H}\right) \in$ продуктами неповного окиснення вуглеводнів палива і утворюються, як правило, на ранніх стадіях його згоряння. Потрапляючи до організму людини інгаляційним шляхом, вони подразнюють слизові оболонки та впливають на роботу центральної нервової системи. ФА, крім того, спричинює пригнічення синтезу нуклеїнових кислот, сенсибілізує шкіру людини та має мутагенні властивості, негативно впливає на репродуктивну функцію організму.

Сполуки Сульфуру (крім $\left.\mathrm{SO}_{2}\right)$ є клітинними і ферментними отрутами, а тому в організмі людини і вищих тварин спричиняють порушення білкового та водного обмінів, а за небезпечних концентрацій - важкі отруєння. При взаємодії з парами води $\mathrm{SO}_{2}$ і $\mathrm{SO}_{3}$ утворюють аерозолі, відповідно, сульфітної та сульфатної кислот i, як наслідок, відбувається порушення функціонування живих організмів, деградація екосистем. При цьому процес окиснення $\mathrm{SO}_{2}$ до $\mathrm{SO}_{3}$ відбувається в атмосферному повітрі досить швидко і великою мірою прискорюється у присутності оксидів Нітрогену.

Дрібнодисперсні частинки сажі, в основному, викидаються дизельними двигунами та $є$ потужними забруднювачами атмосферного повітря, водойм, придорожніх грунтів та грунтових розчинів. Частинки розміром 0,4-5 мкм утворюються внаслідок піролізу вуглеводнів палива при значній нестачі кисню і мають дуже розвинуту, сорбційно активну поверхню. Шкідливі речовини, адсорбуючись на їх поверхні, через дихальні шляхи потрапляють до організмів людини і вищих тварин. РМ також здатні розповсюджуватися на значні відстані від дороги, створюючи вторинні геохімічні аномалії.

Обсяги викидів ШР та їх хімічний склад (у тому числі й токсичність) великою мірою залежать від конструкції і марки АТЗ, його технічного стану, умов і термінів експлуатації, від виду і якості використовуваного палива, технології його виробництва, способів подачі паливно-повітряної суміші, іiї властивостей та режиму спалювання, погодних умов, режиму руху АТЗ, стану дорожнього покриття тощо. Навіть незначні порушення у роботі двигуна можуть у декілька разів збільшити обсяги викидів та спричинити зростання концентрації ШР у ВГ. Бензинові двигуни (зокрема карбюраторні) вважаються основними емітентами чадного газу $\mathrm{CO}$, а емісія оксидів Нітрогену спричинена, в основному, роботою дизельних АТЗ. Погано відрегульований дизель навіть "димить" через надмірні викиди РМ.

Існує декілька методів визначення обсягів викидів ШР з ВГ АТЗ, які в Україні регламентуються відповідними законодавчими актами і нормативними документами [8-11]. У країнах $\mathrm{CC}$, як правило, використовують рекомендовані МАГАТЕ методи, засновані на емпіричній моделі Пасквілла-Гіффорда, а в основу галузевого стандарту України ГСТУ 218-02071168-096-2003 [10] та КД 52.9.4.01-09 покладено рівняння на основі теорії турбулентної дифузії [12].

У дослідженні при моделюванні складних багатопараметричних процесів, що відбуваються у повітряному просторі придорожніх територій рекреаційного призначення, за основу взято методики $[9 ; 13]$, а також удосконалену й апробовану вітчизняними дослідниками методику $[8 ; 11 ; 14]$, що базується на даних пробігових викидів ШР АТЗ на певній ділянці магістралі. Методика враховує залежність обсягу викидів ШР від виду палива і швидкості руху АТЗ, а також наявності та режиму роботи регульованих перехресть. Розрахунки за методикою проводять для таких забруднювальних домішок, як $\mathrm{CO}, \mathrm{NO}_{\mathrm{x}}$, вуглеводні $\mathrm{C}_{\mathrm{x}} \mathrm{H}_{\mathrm{y}}, \mathrm{PM}, \mathrm{SO}_{2}$, ФА, бенз(а)пірен та сполуки Плюмбуму.

$\mathrm{У}$ роботах $[15 ; 16]$ відзначається, що у приземному шарі повітря внаслідок топографічних особливостей місцевості виникають специфічні поля турбулентності, в результаті чого змінюються не тільки горизонтальні і вертикальні потоки повітря, а й розподіл температури та вологості. Ці фактори чинять визначальний вплив на атмосферну дифузію полютантів, спричинюючи їх перемішування, трансформацію і локальне концентрування на певних ділянках території. Отже, поряд з напруженими магістралями через перемішування й взаємодію інгредієнтів ВГ між собою та зі складовими НПС формуються локальні поля забруднення з максимумами і мінімумами концентрацій певних полютантів.

Географічне положення певної території міста (ділянки навколо автомагістралі), іiї орографія тощо обумовлюють специфічні кліматичні умови, які впливають на характер циркуляції повітряних мас. У нижньому шарі повітряного середовища швидкість вітру, як правило, є набагато меншою, ніж в його більш високих шарах, a, отже, у цьому шарі створюються несприятливі умови для надмірного (i навіть надзвичайного) накопичення забруднювачів, особливо тих, які мають більшу за повітря молярну масу $\left(\mathrm{M}_{\text {пов. }}=29\right.$ г/моль). Отже, у такому випадку у приземному шарі атмосферного повітря вітрові потоки відіграють визначальну роль у дисперсії забруднювачів, а наявність штилів зі швидкістю вітру $u \leq 6 \mathrm{~m} / \mathrm{c}$ 


\section{ISSN 1813-5420 (Print). Енергетика: економіка, технології, екологія. 2018. № 4}

призводить до локального накопичення забруднювачів на певній території.

Приземний атмосферний шар характеризується певною стійкістю. У нестійкій атмосфері характерними $є$ конвективні вертикальні потоки, які сприяють інтенсивному перемішуванню повітряних мас. Отже, параметри розсіювання ШР, а саме коефіцієнти їх дисперсії $\sigma_{\mathrm{x}}, \sigma_{\mathrm{y}}$ та $\sigma_{\mathrm{z}}$, безпосередньо пов'язані 3 показником стійкості атмосфери (його позначають $\mathrm{A}, \mathrm{B}, \mathrm{C}, \mathrm{D}, \mathrm{E}, \mathrm{F}$, вважаючи, що від А до F стійкість атмосфери збільшується) [17]. Параметри розсіювання ШР у повітрі (іх дисперсії $\sigma_{y}$ та $\sigma_{z}$ ) виражають за допомогою відповідних коефіцієнтів дифузії $\mathrm{D}_{\mathrm{x}}$ i $\mathrm{D}_{\mathrm{z}}$ :

$$
\sigma_{y}^{2}=2 D_{y} x ; \quad \sigma^{2}=2 D_{z} x .
$$

$\sigma_{y}$ та $\sigma_{z}$ визначають також або за номограмами [17], або емпірично, за рівнянням (3):

$$
\sigma_{\mathrm{y}}=\alpha_{\mathrm{y}} \mathrm{x} / \mathrm{S}_{1}(\mathrm{x}) ; \quad \sigma_{\mathrm{z}}=\alpha_{\mathrm{z}} \mathrm{x} / \mathrm{S}_{2}(\mathrm{x}),
$$

де $\mathrm{S}_{1}=\left(1+\beta_{1} \mathrm{X}\right)^{1 / 2} ; \mathrm{S}_{2}=\left(1+\beta_{2} \mathrm{X}\right)^{1 / 2}$; коефіцієнт $\beta_{1}=1 \cdot 10^{-4}$; інші параметри подано у таблиці.

Таблиця - Значення параметрів розсіювання шкідливих домішок у повітрі $\alpha_{y} ; \alpha_{z}$ та $\beta_{2}$

\begin{tabular}{|c|c|c|c|}
\hline $\begin{array}{c}\text { Клас стійкості } \\
\text { атмосфери }\end{array}$ & $\alpha_{\mathrm{y}}$ & $\alpha_{\mathrm{z}}$ & $\beta_{2}$ \\
\hline $\mathrm{A}$ & 0,22 & 0,2 & 0 \\
\hline $\mathrm{B}$ & 0,16 & 0,12 & 0 \\
\hline $\mathrm{C}$ & 0,11 & 0,08 & $1,5 \cdot 10^{-4}$ \\
\hline $\mathrm{D}$ & 0,008 & 0,06 & $2 \cdot 10^{-4}$ \\
\hline $\mathrm{E}$ & 0,06 & 0,03 & $3 \cdot 10^{-4}$ \\
\hline $\mathrm{F}$ & 0,04 & 0,02 & $3 \times 10^{-4}$ \\
\hline
\end{tabular}

3 метою моделювання полів розсіювання забруднювачів від АТП проводили просторово-часові натурні обстеження їх інтенсивності та складу на магістралях столиці, що прилягають до зон відпочинку людей. Дані щодо кількості АТЗ на певній ділянці магістралі та режиму їх руху реєстрували за допомогою відеозйомки. Спостереження проводили у різні пори року та у дні, коли не було сильних атмосферних опадів та за відсутності транспортних заторів. Відеозйомку проводили тричі по 20 хв. для кожного поста в обох

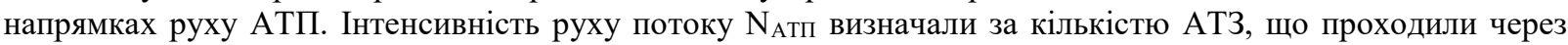

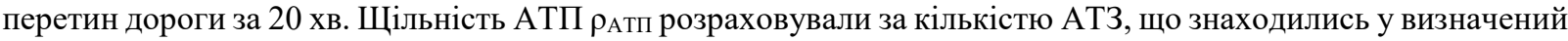
момент часу на досліджуваній ділянці дороги. За цим показником визначали також завантаженість магістралі. Склад АТП характеризували співвідношенням у ньому АТЗ певного типу - легкових автомобілів, мікроавтобусів, автобусів, вантажівок тощо; окремо встановлювали частку дизельного автотранспорту.

Для моделювання полів розсіювання й концентрування ШР у придорожньому просторі на територіях, що мають рекреаційне призначення, крім основних характеристик АТП, визначали також:

- географічне положення початку і кінця досліджуваної ділянки магістралі (встановлювали за допомогою програмного комплексу Google Maps та GPS);

- довжину ділянок L з фіксацією вулиць, що їх перетинають та/або обмежують;

- ширину проїжджої частини $\mathrm{b}$ та наявність поздовжнього нахилу;

- ширину тротуарів $\mathrm{b}_{\text {тр }}$ (за наявності), наявність та ширину захисної "зеленої" полоси, ії рослинність тощо;

- відстань до найближчої забудови, характер і щільність забудови;

- кількість смуг руху у кожному напрямку дороги;

- середню швидкість руху АТП

- синоптичні та метеорологічні умови;

- шорсткість підстилаючої поверхні, наявність поряд з дорогою водних об'єктів тощо.

Для побудови математичних моделей розсіювання й локального концентрування ШР у приземному шарі придорожнього простору на територіях рекреаційного призначення використовували метод М. Є. Берлянда [18] в інтерпретації В. О. Холоднова з колегами [19]. Ідея методу полягає в тому, що у програмному комплексі MathCad реалізується модель факельного наближення, за допомогою якої розв'язується напівемпіричне рівняння турбулентної дифузії у декартових координатах для лінійного джерела як сукупності точкових джерел викидів на основі принципу суперпозиції полів концентрацій певної шкідливої домішки. Результат розрахунку приземних 
концентрацій ШР подається у кратності перевищення ії ГДК м.р., причому отримані поля дисперсії є функцією 3-х, а у випадку нестаціонарності процесу - 4-х параметрів (додається час). У такому разі математичну модель розсіювання ШР отримуємо у вигляді системи диференційних рівнянь у часткових похідних, розв'язок якої можливий тільки за певних граничних умов.

Рівень небезпеки забруднення повітря для здоров'я людей визначали за найбільшою концентрацією забруднювача, розрахованою за небезпечних метеорологічних умов - у найтепліший місяць року та при небезпечній швидкості вітру [20]. На рис. 2 показано приклад побудови полів дисперсії $\mathrm{PM}, \mathrm{NO}_{\mathrm{x}}$ та $\mathrm{CO}$ за найбільш небезпечного напрямку вітру і швидкості вітру 5 м/с на території поряд з озерами № 14 та № 15 по вул. Миколи Ушакова - проспект Перемоги - Брест-Литовське шосе (м. Київ), яка $є$ зоною активного відпочинку людей. Під час підрахунків вважали, що дисперсія частинок РМ 3 розміром $\leq 10$ мкм підпорядковується закономірностям, характерним для дисперсії газів, а для більш крупних частинок ці закономірності суттєво змінюються [21].

Для отриманих моделей дисперсії ШР запропоновано таку градацію Р3 придорожнього простору (не враховуючи синергетичні ефекти забруднення НПС кількома речовинами, а також геометричні особливості руху АТП ділянками магістралей міста):

- екологічно небезпечне середовище, якщо кратність перевищення ГДК домішки становить від 8,0 ГДК і вище,

- високий рівень забруднення, якщо це відношення 4,4 ..8,0,

- середній Р3 - кратність перевищення ГДК ШР 1...4,4 ГДК;

- екологічно безпечний рівень, якщо немає перевищення ГДК.

\section{Висновки}

1. Таким чином, за інтегральним показником ІЗА встановлено, що РЗ АП м. Києва впродовж останніх років знаходиться на високому рівні. Київ майже кожного року входить до списку міст 3 серйозними екологічними проблемами, ризиками підвищення захворюваності населення тощо. Проблема посилюється i тим, що останніми роками в країні все частіше експлуатуються уживані АТЗ з двигунами екологічних класів Євро 1...Свро 3.

2. Процес дисперсії ШР визначається умовами їх емісії, особливостями горизонтального і вертикального переносу, в тому числі й турбулентного. Розсіювання ШР у повітрі відбувається, по-перше, через конвективне перенесення повітряних мас, зокрема, у напрямку середнього вітру; по-друге, через дифузійні процеси, пов'язані з градієнтом концентрації певного забруднювача і, по-третє, внаслідок турбулентної дифузії - перемішування повітряних мас у всіх напрямках. Таким чином, на процеси розсіювання й локального концентрування ШР у повітряному просторі та на певній території впливають напрям і швидкість вітру, метеорологічні умови, фізико-хімічні властивості певного забруднювача, можливості його трансформації у довкіллі, умови седиментації та/або вторинного механічного перенесення.

3. Для встановлення закономірностей дисперсії ШР від АТП у міському придорожньому просторі та прогнозування екологічного стану територій рекреаційного призначення у середовищі MathСad побудовано просторові математичні моделі полів концентрацій домішок - $\mathrm{CO}, \mathrm{NO}_{\mathrm{x}}$ та $\mathrm{PM}$. Враховуючи, що вітровий режим є одним з найвпливовіших чинників, який визначає розсіювання домішки у потоці повітря, отримано поля концентрацій (дисперсіі) забруднювачів на придорожніх ділянках рекреаційного призначення за небезпечного напрямку середнього вітру та різних значень його швидкості (1-5 м/c).

4. За характеристиками АТП на магістралі, розташованої поблизу досліджуваної території рекреаційного призначення (на прикладі зон відпочинку м. Києва), встановлено території потенційно підвищеного екотоксикологічного ризику. Побудовано й візуалізовано математичні моделі розсіювання та локального концентрування забруднювачів - інгредієнтів викидів ШР АТЗ. За допомогою обчислювального експерименту встановлено найнебезпечніший для певної ділянки напрямок вітру та його швидкість, спрогнозовано розвиток екологічної ситуації на території за різних метеорологічних умов.

5. Методом моделювання встановлено, що на певних ділянках міської території, що є зоною відпочинку, унаслідок формування техногенних аномалій певних забруднювачів тривале знаходження людей є небезпечним для їх здоров’я, особливо в часи, коли відбувається інтенсивний рух АТЗ. 

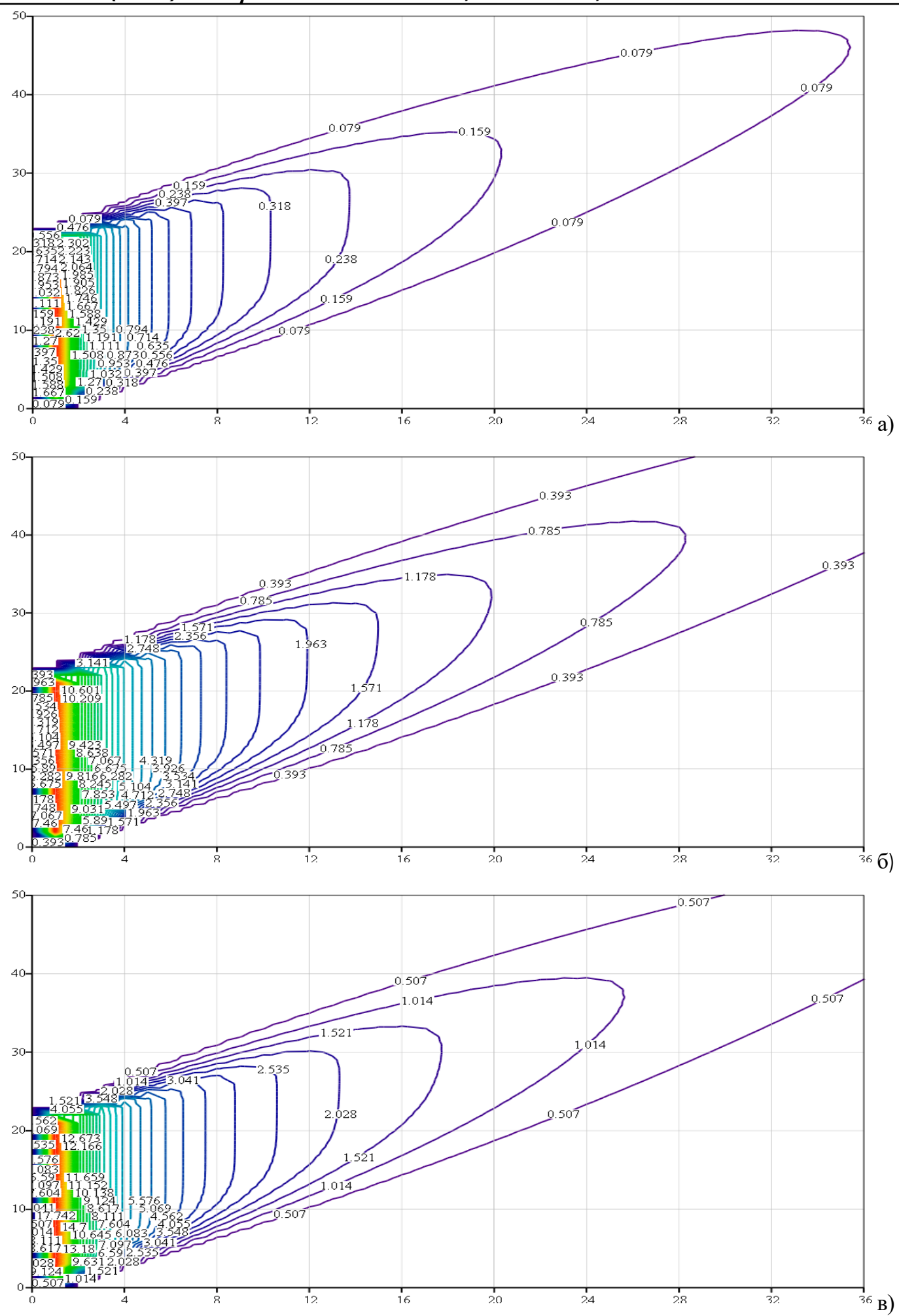

Рисунок 2 - Поля дисперсії ШР на досліджуваній території рекреаційного призначення (поряд з озером № 15 , м. Київ) при найбільш небезпечному західному вітрі зі швидкістю 5 м/с: а) PM; б) NO ; в) CO.

\section{Список використаної літератури}

1. Основные направления обеспечения национальной безопасности Республики Беларусь. Современное состояние и перспективы : монография / под науч. ред. Мясниковича М. В., Пузикова В. В. - Минск : Экономика и право - 2003. - $451 \mathrm{c}$.

2. Гичев Ю.П. Здоровье человека как индикатор экологического риска индустриальных регионов // Вестн. Poc. AMH. - 1995. - № 8. - C. 52-54. 
3. Центральна геофізична обсерваторія імені Бориса Срезневського. Про стан забруднення навколишнього природного середовища у м. Києві і Київській області у березні 2018 р. Атмосферне повітря [Електронний ресурс] : [Сайт]. - Режим доступу : http://cgo-sreznevskyi.kiev.ua/index.php?fn=k_zabrud\&f=kyiv. - Дата доступу : 14.04.2018 p.

4. Елементи сучасної урбоекології : навч. посіб. [Електронний ресурс] / [О. Запорожець, Я. Мовчан, В. Гавриленко, Р. Гаврилюк та ін.]. - К. : НАУ, 2015. - 265 с. - Режим доступа : http://er.nau.edu.ua:8080/handle/ NAU/27087. - Назва з екрана.

5. Центральна геофізична обсерваторія імені Бориса Срезневського [Електронний ресурс] : [Сайт]. - Режим доступу : http://cgo-sreznevskyi.kiev. ua/.

6. Берлянд М. Е. О методах определения фонового загрязнения атмосферы в городах / [М. Е. Берлянд, Э. Ю. Безуглая, Е. Л. Генихович и др.] // Труды ГГО им. А. И. Воейкова. - Л. : Гидрометеоиздат, 1984. - Вып. 479. - С. $17-30$.

7. Транспортна екологія. Методично-інформаційні матеріали до самостійного вивчення дисципліни та виконання індивідуальних завдань [для студ. напряму підготов. 6.070101 Транспортні технології (за видами транспорту)] / [А. В. Павличенко, С. М. Лисицька, О. О. Борисовська, О. В. Деменко]. - Дніпропетровськ : Нац. гірничий ун-т, 2012. - 39 с.

8. Матейчик В. П. Оцінка рівня забруднення атмосферного повітря транспортними потоками / Матейчик В. П., Никонович С. О., Сапожник Ю. В. // Вісник Нац. транспортного ун-ту. - 2013. - № 27. - С. 78-83.

9. Методика розрахунку викидів забруднюючих речовин та парникових газів у повітря від транспортних засобів. Наказ Державного комітету статистики України № 452 від 13.11.2008 [Електронний ресурс]. - Режим доступу : http://uazakon.com/documents/date_3a/pg_gmcywc/ index.htm. - Назва з екрана.

10. ГСТУ 218-02071168-096-2003. Охорона навколишнього середовища. Автомобільні дороги загального користування. Оцінка та прогнозування екологічного стану доріг та виробничих баз. Видання офіційне. - Державна служба автомобільних доріг України (Укравтодор). - Київ, 2003. - 48 с.

11. Матейчик В. П. Розробка методики визначення витрат палива та масових викидів забруднюючих речовин транспортним потоком / Матейчик В. П., Никонович С. О. // Вісник Нац. транспортного ун-ту. - К : НТУ. - 2011. № 24 (2). - С. 93-99.

12. КД 52.9.4.01-09 Охорона природи. Атмосфера. Методичні вказівки щодо прогнозування метеорологічних умов формування рівнів забруднення повітря в містах України. - Видання офіційне; Державна гідрометеорологічна служба. - К., 2010. - 78 с.

13. Методика определения выбросов автотранспорта для проведения сводных расчетов загрязнения атмосферы городов [Електронний ресурс]. - СПб., 2010 - 15 с. // Фирма "Интеграл"; от 20.10.16. - Режим доступу: http://forum.integral.ru/viewtopic.php?f=64\&t=16815. - Назва з екрана.

14. М 218-02070915-694:2011 Оцінювання інгредієнтного і параметричного забруднення придорожнього середовища системою "транспортний потік-дорога" [Електронний ресурс ] / [К. : НТУ, 2011; дата прийняття 01.01.2011 p.]. - Режим доступу: http://online.budstandart.com/ua/catalog/doc-page?id_doc=27916. - Назва $з$ екрана.

15. Численное моделирование распостранения загрязнения в окружающей среде / [М. З. Згуровский, В. В. Скопецкий, В. К. Хрущ, Н. Н. Беляев]. - К. : Наукова думка, 1997. - 367 с.

16. Оленьков В. Д Учет ветрового режима городской застройки при градостроительном планировании с использованием технологий компьютерного моделирования / В. Д. Оленьков // Вестник ЮУрГУ. Сер. "Строительство и архитектура". - 2017. - т. 17. - № 4. - С. 21-27. DOI: 10.14529/build170403.

17. Абрамовський Є. Р. Атмосфера великих міст / Є. Р. Абрамовський, В. І. Карплюк, М. М. Переметчик. Дніпропетровськ : Наука і освіта, 2011. - 350 с.

18. Берлянд М. Е. Современные проблемы атмосферной диффузии и загрязнения атмосферы / М. Е. Берлянд. - Л. : Гидрометеоиздат, 1975. - 448 c.

19. Системный анализ и принятие решений. Компьютерное моделирование и оптимизация объектов химической технологии в Mathcad и Excel : учеб. пособ. / В. А. Холоднов, В. П. Решетиловский, М. Ю. Лебедева, Е. С. Боровинская. - СПб :СПбГТИ (ТУ), 2007. -425 с.

20. Оцінка ризику для здоров'я населення від забруднення атмосферного повітря : [метод. рекомендації] // МО3 України; [затверджено за наказом МОЗ України від 13.04.2007 p. №184]. - Офіційне видання, 2007. - 28 с.(Нормативний документ МОЗ України).

21. Медников Е. П. Турбулентный перенос и осаждение аэрозолей / Е. П. Медников. - М. : Наука. - 1980. $176 \mathrm{c}$. 


\section{O. Borysov, Ph.D. student, ORCID 0000-0002-1053-2989 \\ O. Kofanov, Cand. Sc. (Eng.), TF, ORCID 0000-0003-2181-9288 \\ National Technical University of Ukraine 'Igor Sikorsky Kyiv Polytechnic Institute' ECOLOGICAL LOAD ON THE ROADSIDE RECREATIONAL AREAS CAUSED BY TRAFFIC FLOWS}

The paper investigates the influence of traffic flows on the urban roadside recreational areas (on the example of the Kyiv recreation areas). The relevance of the study is substantiated by the fact that a significant part of the urban population of Ukraine lives in the conditions of the high or even extremely high levels of environmental pollution. The problem is also amplified by the fact that in recent years the used motor vehicles with engines of environmental classes Euro 1...Euro 3 are increasingly being used in the country. It has been empirically determined that the direction and velocity of the wind, various meteorological conditions, physical and chemical properties of the pollutants, as well as the processes of their transformation in the environment and the conditions of sedimentation and/or secondary mechanical transfer influence the processes of dispersion and concentration of pollutants in certain areas. In order to predict the ecological state of the studied recreational areas, the spatial mathematical models of the concentration fields of harmful impurities (in particular Nitrogen and Carbon oxides, PM) for the hazardous directions and wind speeds were developed in the MathCad environment, based on the solution of the turbulent diffusion equation. According to the modelling results, it has been established that the studied recreational areas are potentially dangerous to the health of people due to the harmful effects of emissions from traffic flows located along the highways. With the help of the computational experiment, the ecological state on these territories was predicted in given meteorological conditions and transport situation.

Keywords: traffic flow, ecological safety, harmful substances, emissions from vehicles, recreational territories, environmental pollution.

\section{References}

[1] Osnovnye napravleniya obespecheniya natsional'noy bezopasnosti Respubliki Belarus'. Sovremennoe sostoyanie i perspektivy : monografiya / pod nauch. red. Myasnikovicha M. V., Puzikova V. V. - Minsk : Ekonomika i pravo - 2003. - $451 \mathrm{~s}$.

[2] Gichev Yu.P. Zdorov'e cheloveka kak indikator ekologicheskogo riska industrial'nykh regionov // Vestn. Ros. AMN. - 1995. - № 8. - S. 52-54.

[3] Centraljna gheofizychna observatorija imeni Borysa Sreznevsjkogho. Pro stan zabrudnennja navkolyshnjogho pryrodnogho seredovyshha u m. Kyjevi i Kyjivsjkij oblasti u berezni 2018 r. Atmosferne povitrja [Elektronnyj resurs] : [Sajt]. - Rezhym dostupu : http://cgo-sreznevskyi.kiev.ua/index.php?fn=k_zabrud\&f=kyiv. - Data dostupu : 14.04.2018 r.

[4] Elementy suchasnoji urboekologhiji : navch. posib. [Elektronnyj resurs] / [O. Zaporozhecj, Ja. Movchan, V. Ghavrylenko, R. Ghavryljuk ta in.]. - K. : NAU, 2015. - 265 s. - Rezhym dostupa : http://er.nau.edu.ua:8080/handle/ NAU/27087. - Nazva z ekrana.

[5] Centraljna gheofizychna observatorija imeni Borysa Sreznevsjkogho [Elektronnyj resurs] : [Sajt]. - Rezhym dostupu : http://cgo-sreznevskyi.kiev.ua.

[6] Berlyand M. E. O metodakh opredeleniya fonovogo zagryazneniya atmosfery v gorodakh / [M. E. Berlyand, E. Yu. Bezuglaya, E. L. Genikhovich i dr.] // Trudy GGO im. A. I. Voeykova. - L. : Gidrometeoizdat, 1984. - Vyp. 479. - S. $17-30$.

[7] Transportna ekologhija. Metodychno-informacijni materialy do samostijnogho vyvchennja dyscypliny ta vykonannja indyvidualjnykh zavdanj [dlja stud. naprjamu pidghotov. 6.070101 Transportni tekhnologhiji (za vydamy transportu)] / [A. V. Pavlychenko, S. M. Lysycjka, O. O. Borysovsjka, O. V. Demenko]. - Dnipropetrovsjk : Nac. ghirnychyj un-t, 2012. $-39 \mathrm{~s}$.

[8] Matejchyk V. P. Ocinka rivnja zabrudnennja atmosfernogho povitrja transportnymy potokamy / Matejchyk V.P., Nykonovych S. O., Sapozhnyk Ju. V. // Visnyk Nac. transportnogho un-tu. - 2013. - \# 27. - S. $78-83$.

[9] Metodyka rozrakhunku vykydiv zabrudnjujuchykh rechovyn ta parnykovykh ghaziv u povitrja vid transportnykh zasobiv. Nakaz Derzhavnogho komitetu statystyky Ukrajiny \# 452 vid 13.11.2008 [Elektronnyj resurs]. - Rezhym dostupu : http://uazakon.com/documents/date_3a/pg_gmcywc/ index.htm. - Nazva z ekrana.

[10] GhSTU 218-02071168-096-2003. Okhorona navkolyshnjogho seredovyshha. Avtomobiljni doroghy zaghaljnogho korystuvannja. Ocinka ta proghnozuvannja ekologhichnogho stanu dorigh ta vyrobnychykh baz. Vydannja oficijne. - Derzhavna sluzhba avtomobiljnykh dorigh Ukrajiny (Ukravtodor). - Kyjiv, 2003. - 48 s.

[11] Matejchyk V. P. Rozrobka metodyky vyznachennja vytrat palyva ta masovykh vykydiv zabrudnjujuchykh rechovyn transportnym potokom / Matejchyk V. P., Nykonovych S. O. // Visnyk Nac. transportnogho un-tu. - K : NTU. 2011. -\# 24 (2). - S. 93-99.

[12] KD 52.9.4.01-09 Okhorona pryrody. Atmosfera. Metodychni vkazivky shhodo proghnozuvannja meteorologhichnykh umov formuvannja rivniv zabrudnennja povitrja v mistakh Ukrajiny. - Vydannja oficijne; Derzhavna ghidrometeorologhichna sluzhba. - K., 2010. - 78 s. 
[13] Metodika opredeleniya vybrosov avtotransporta dlya provedeniya svodnykh raschetov zagryazneniya atmosfery gorodov [Elektronniy resurs]. - SPb., 2010 - 15 s. // Firma "Integral"; ot 20.10.16. - Rezhim dostupu: http://forum.integral.ru/viewtopic.php?f=64\&t=16815. - Nazva z ekrana.

[14] M 218-02070915-694:2011 Ocinjuvannja inghredijentnogho i parametrychnogho zabrudnennja prydorozhnjogho seredovyshha systemoju "transportnyj potik-dorogha" [Elektronnyj resurs ] / [K. : NTU, 2011; data pryjnjattja 01.01.2011 r.]. - Rezhym dostupu: http://online.budstandart.com/ua/catalog/doc-page?id_doc=27916. - Nazva z ekrana.

[15] Chislennoe modelirovanie raspostraneniya zagryazneniya v okruzhayushchey srede / [M. Z. Zgurovskiy, V. V. Skopetskiy, V. K. Khrushch, N. N. Belyaev]. - K. : Naukova dumka, 1997. - 367 s.

[16] Olen'kov V. D Uchet vetrovogo rezhima gorodskoy zastroyki pri gradostroitel'nom planirovanii s ispol'zovaniem tekhnologiy komp'yuternogo modelirovaniya / V. D. Olen'kov // Vestnik YuUrGU. Ser. "Stroitel'stvo i arkhitektura". - 2017. - t. 17. - № 4. - S. 21-27. DOI: 10.14529/build170403.

[17] Abramovsjkyj Je. R. Atmosfera velykykh mist / Je. R. Abramovsjkyj, V. I. Karpljuk, M. M. Peremetchyk. Dnipropetrovsjk : Nauka i osvita, 2011. - $350 \mathrm{~s}$.

[18] Berlyand M. E. Sovremennye problemy atmosfernoy diffuzii i zagryazneniya atmosfery / M. E. Berlyand. - L. : Gidrometeoizdat, 1975. - 448 s.

[19] Sistemnyy analiz i prinyatie resheniy. Komp'yuternoe modelirovanie i optimizatsiya ob"ektov khimicheskoy tekhnologii v Mathcad i Excel : ucheb. posob. / V. A. Kholodnov, V. P. Reshetilovskiy, M. Yu. Lebedeva, E. S. Borovinskaya. - SPb :SPbGTI (TU), 2007. - $425 \mathrm{~s}$.

[20] Ocinka ryzyku dlja zdorov'ja naselennja vid zabrudnennja atmosfernogho povitrja : [metod. rekomendaciji] // MOZ Ukrajiny; [zatverdzheno za nakazom MOZ Ukrajiny vid 13.04.2007 r. \#184]. - Oficijne vydannja, 2007. - 28 s.(Normatyvnyj dokument MOZ Ukrajiny).

[21] Mednikov E. P. Turbulentnyy perenos i osazhdenie aerozoley / E. P. Mednikov. - M. : Nauka. - 1980. $-176 \mathrm{c}$.

\section{А.А. Борисов, аспірант ORCID 0000-0002-1053-2989 \\ A.E. Кофанов , канд. тех. наук, асистент ORCID 0000-0003-2181-9288 \\ Национальный технический университет Украины \\ ЭКОЛОГИЧЕСКАЯ НАГРУЗКА СО СТОРОНЫ АВТОТРАНСПОРТНЫХ ПОТОКОВ НА ПРИДОРОЖНЫЕ ТЕРРИТОРИИ РЕКРЕАЦИОННОГО НАЗНАЧЕНИЯ}

В работе исследовано влияние автотранспортных потоков на городские придорожные рекреационные территории (на примере зон отдыха г. Киева). Актуальность исследования обусловлена тем, что значительная часть городского населения Украины живет в условиях повышенных, высоких или даже очень высоких уровней загрязнения окружающей среды. Проблема усугубляется и тем, что в последние годы в стране все чаще эксплуатируются подержанные автотранспортные средства с двигателями экологических классов Евро 1 ... Евро 3. Эмпирически установлено, что на прочессы рассеивания и концентрирования загрязнителей на конкретных территориях влияют направление и скорость ветра, метеорологические условия, физико-химические свойства веществ-загрязнителей, процессы их трансформации в окружающей среде, а также условия седиментации и/или вторичного механического переноса. Для прогнозирования экологического состояния исследуемых рекреационнных территорий в среде МаthСаd на основе решения уравнения турбулентной диффузии построены пространственные математические модели полей концентраций вредных примесей, в том числе оксидов азота, углерода и мелкодисперсной пыли РМ с учетом опасных направлений и скоростей ветра. По результатам моделирования установлено, что исследуемые придорожные территории, являющиеся зонами отдыха людей, представляют потенциальную опасность для их здоровья из-за вредного воздействия компонентов выбросов автотранспортных потоков расположенных рядом автомагистралей. С помощьью вычислительного эксперимента спрогнозировано развитие экологической ситуации на данньх территориях при определенной транспортной ситуации и метеорологических условиях.

Ключевые слова: автотранспортный поток, экологическая безопасность, вредные вещества, выбросы автотранспортных средств, рекреационные территории, загрязнение окружающей среды.

Надійшла 18.02.2019

Received 18.02.2019 